\title{
The Conflicts Between Law School Education and Judicial Profession in China: Predicament and Outlet
}

\author{
Kai Chen \\ School of Law, Xiamen University, Xiamen 361005, China. \\ xmuchenkai@gmail.com
}

Keywords: China, law school education, judicial profession, predicament, outlet.

\begin{abstract}
By exploring the the diversity information between data from China's National Bureau of Statistics, this Article finds that the scale and quantity of law school education in China are increasing at all times. This education focus on quantity, which makes someone shocking and raises our serious concerns. Gradually, many people suppose this law school education that only focus on scale and quantity would be a kind of bubble which are inevitably waiting for burst. In relation to judicial profession, this Article indicates that one who intends to be a judge should pass the National Judicial Examination, and then pass the Civil Service Examination, and in addition, he/she should serve as a Court Clerk for a period of time. According to that, it is hard to become a judge in a hurry. There are two contribution in this Article. First, this Article points out that there are two conflicts between law school education and judicial profession in China, which need to repair as quickly as possible: (1) a conflict between the comprehensiveness of law school education and the professionalism of judicial profession; (2) a conflict between the intellectualism of law school education and the practicalness of judicial profession. Second, this Article explores the solution resolving the conflicts.
\end{abstract}

\section{Introduction}

In China, the law school education was resumed along with the resuming of the College Entrance Examination System, and it began to expand in 1990s. Admittedly, the flourish of law school education is directly related to the social demand for legal talents, but does the law school education meets the demand of judicial profession?

The first part of this Article attempts to explore the present situation of the law school education in China by analysing the quantitative study on the number of law school students and the practical development of teaching content. In the second part, this Article wants to show the current mechanism of judge selection in China, and it indicates that one who wants to become a judge requires multiple assessments, such as the National Judicial Examination, the Civil Service Examination, and the Court Clerk. Because of the Judge Post System of Judicial Reform of China, it is more hard to be a judge than before, the possibility to be a judge are getting lower. The third part seeks to discuss the conflicts between law school education and judicial profession in China, and the presents solutions for all of them. The last part is the conclusion.

\section{The Present Situation of the Law School Education in China}

As the opinions of most scholars and political officials, the China law school education is in some kind of crisis and on the verge of bubbles that will easily burst. Since the colleges and universities in China began to expand in 1990s, the law school education was also in this wave and pursued the virtual aureole of enrollment plan. Therefore the growing numbers of students caused that it is difficult to obtain employment, and a range of other issues followed. Law school are exploring some new educational pattern, for example learning from the American model, but it produces very little effect, and these explorations are still in progress.

\subsection{The Quantitative Study on the Number of Law School Students.}

The law school education was resumed along with the resuming of the College Entrance Examination System, and it began to expand in 1990s. Legal profession proposed the market 
demand for vocational education, especially after the enactment of the PRC's Act of Lawyer, the PRC's Act of Judge and the PRC's Act of Public Procurator, and this is a further stimulus to the scale of legal education.[1] Admittedly, the flourish of law school education is directly related to the social demand for legal talents. The science of law is gradually becoming a famous school. This can be clearly displayed by the quantitative study on the number of law school students. As shown in following Fig. 1 and Fig. 2: [2]

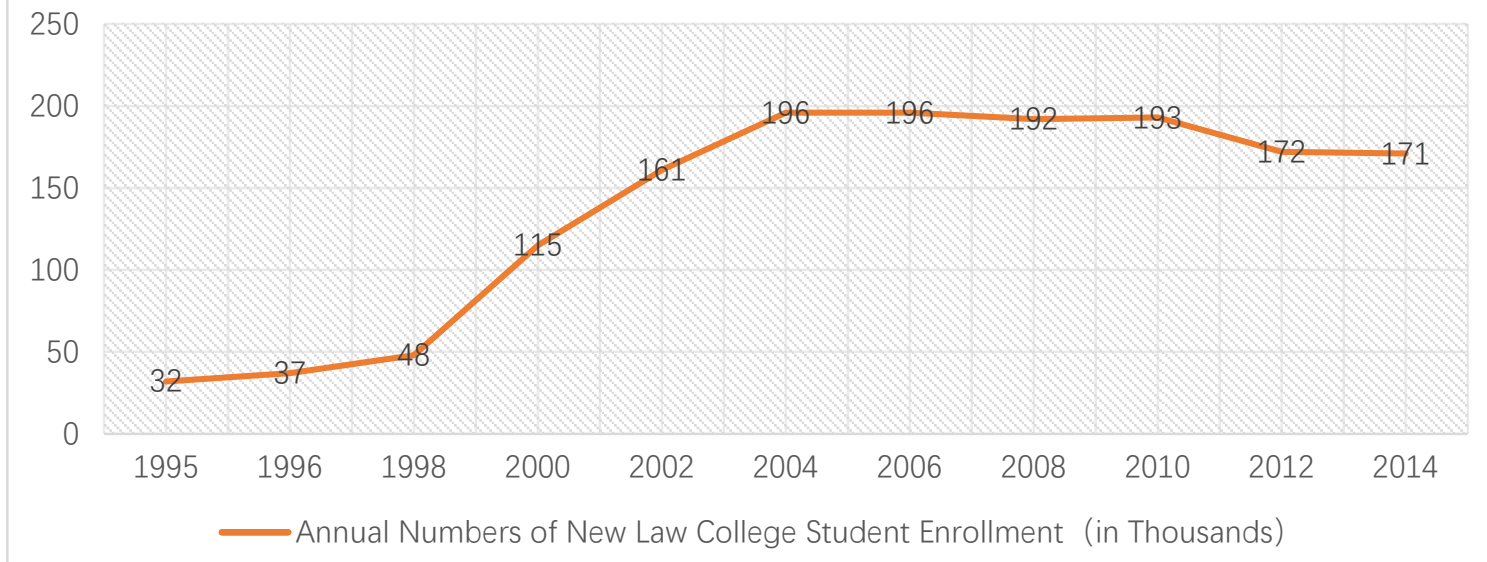

Fig. 1 The Annual Numbers of New Law College Student Enrollment (in Thousands)

We can clearly see from the Fig. 1 that the university law student enrollment has risen sharply starting from the end of 20th century, and the enrollment was twice more than previous years. The enrollments in 2004 and 2006 were four times before the sharply risen, after that the enrollment had stabilized, despite a slight drop.

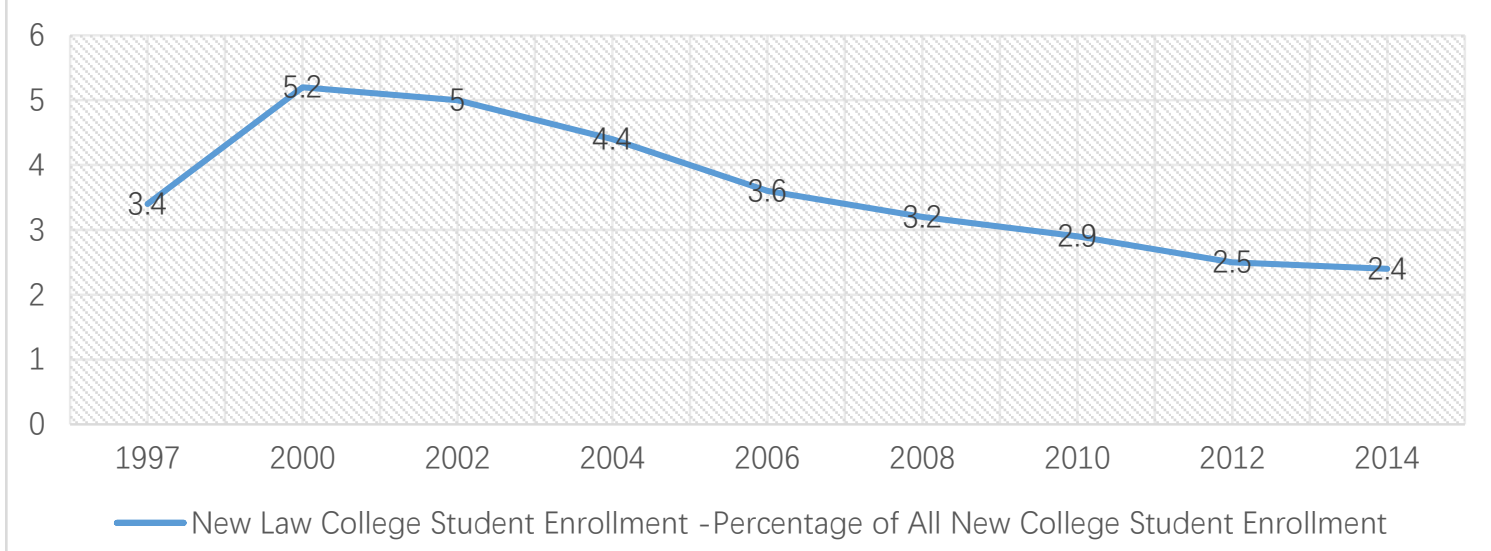

Fig. 2 The New Law College Student Enrollment -Percentage of All New College Student Enrollment

The Fig. 2 is clearly showing that the new law college student enrollment -Percentage of all new college student enrollment has risen sharply starting from the end of 20th century, and to reach its peak in 2000, then slowly decreasing. The Fig. 2 demonstrates that the Percentage may decline further.

In the terms of the new law college student enrollment, the explosive number increased continuing nearly 20 years, which leaded to the crisis of law school education. The most obvious one is that the employment situation is not optimistic. The 2016 Chinese College Students' Employment Report shows that the employment situation of graduates from law school was the worst but one. [3] Although the Percentage has decreased year by year, it still couldn't find a way out of this dilemma.

\subsection{The Practical Development of Teaching Content.}

The law school education of China has preferred to teach knowledge before the reforms in 1995, it almost didn't pay attention to practicalness of law education. April 1995, China's State Council Academic Degree Committee at its 13th session established the Juris Master Education Project, and the law school education of China began to develop, as well as separated itself from "young”. Then 
in 1996 China started to try a national trial for China J.M. Degree, henceforth the law school education of China gradually payed attention to practical teaching contents. In 2006, national J.M. education became a full member over a period of 10 years of experimental work. Simultaneously, the number of colleges that got J.M college enrollment qualification suddenly risen to 80 . As we knew, China J.M. Degree has a specific legal profession background in law, which mainly aims to develop the high-level legal professionals and management personnel, including legislator, judge, lawyers, attorney, public procurator, and so on. [4]

It might be argued that this indicates that China shifted decisively in law school education: further emphasizing cultivation of the applied talents, expanding educational scale of J.M. Degree, improving the quality and level of J.M. Degree. Thereafter, many universities in China have established J.M. Education, and next focused on the practical development of legal education.

For that reasons, many universities in China have already explored the Clinical Legal Education in China, the development of this educational pattern mostly borrowed from American Clinical Legal Education. Since the 2000 academic year, with funding from the Ford Foundation, 10 famous law schools gradually implemented the Clinical Legal Education, such as Zhongshan University, Renmin University of China, Tsinghua University, Peking University, Wuhan University, Zhongnan University, East China University of Political Science and Law, Fudan University, Sichuan University, Northwestern University. This Education pattern plays the initiative of students and improves the students' participation. [5]

Generally speaking, this practical development is subject to the National Judicial Examination, because this Examination is a necessary precondition for almost all legal professional, such as the legislator, judge, lawyers, attorney, public procurator, and so on. At the same time, college school needs to increase employment rate, so that in law school teaching process, law teachers often invoke the Exam Questions of National Judicial Examination. As a result, "the National Judicial Examination affects law education in a certain extent, and many law schools in recent years are changing their curriculum and teaching methods, this is almost a response to the National Judicial Examination.”[6]

\section{The Current Mechanism of Judge Selection in China}

As mentioned earlier, after graduating from law school, many law students are not necessarily intended to and necessarily able to enter the legal profession. In the case of judges, National Judicial Examination is a prerequisite. But almost immediately, they must take a Civil Servant Examination that once or twice a year (according to the policy of each province). After passed the Civil Servant Examination that like an army on a single foot log, he/she is still unable to successfully become a judge, he/she should bear the Court Clerks Phase for one year or two, even more. In the end, he/she can formally become a judge after multiple assessments. Along with Judicial Reform in recent years, the Judge Post System of Judicial Reform of China makes a growing number of law school students stay away from courts.

\subsection{Prerequisite: National Judicial Examination.}

There will be the National Judicial Examination in mid - September of each year in China. It has been successfully carried out for 15 years since the implementation of National Judicial Examination in 2002. During the past 15 years, nearly 500,000 legal talents have been selected by the National Judicial Examination. One who serves as lawyer, judge, prosecutor and notarie must pass the National Judicial Examination. The contents of this Examination are including the application of theory of law, jurisprudence, existing legal provisions, legal practice and legal ethics, and so on.

It might be argued that the Examination is the most difficult exams in China, and in general, almost every law school graduates would take this Examination. Even if failed, he/she will continue to participate until approved.

The total number of those who pass the National Judicial Examination is up to 450,000 by the year 2012. As shown in Fig. 3. [7] 


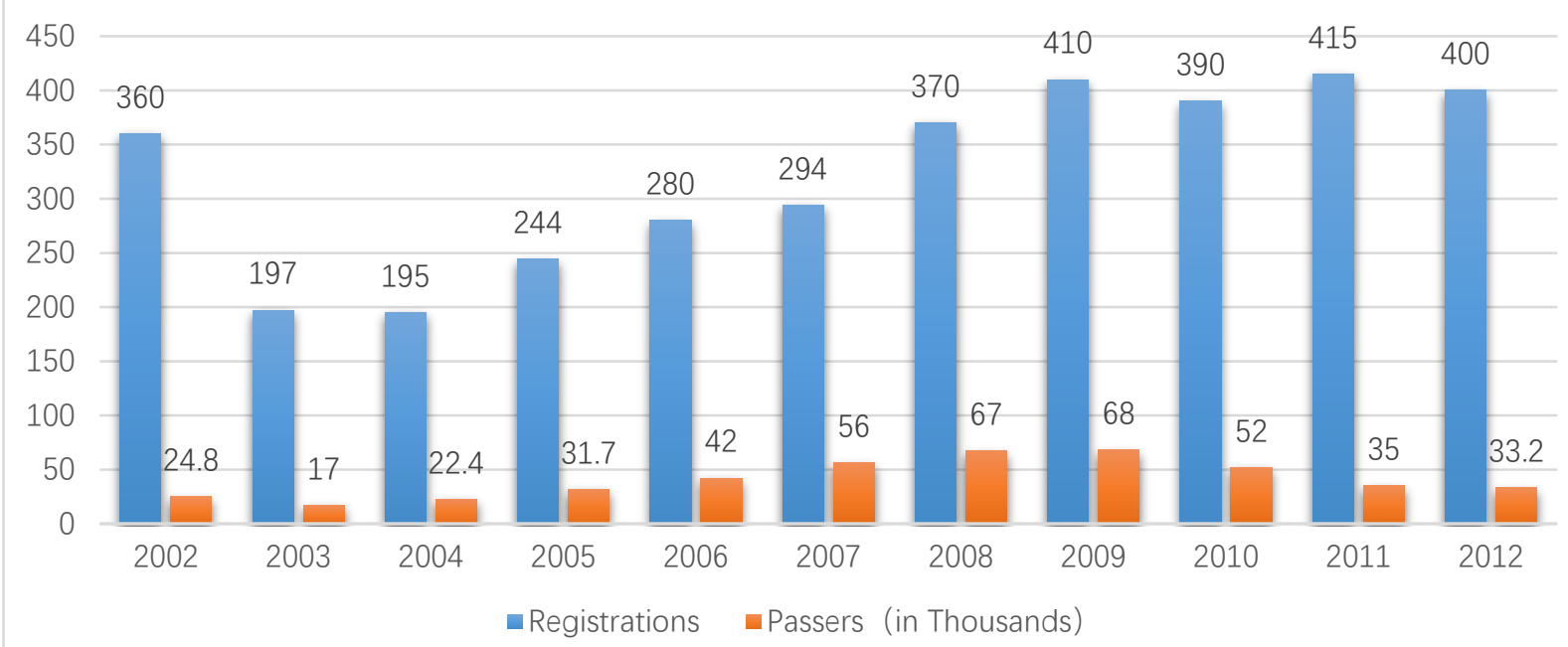

Fig. 3 The Total Number Every Year of Those Who Pass the National Judicial Examination (2002 2012)

We can almost tell from above that the number of registrations of the National Judicial Examination increased gradually starting from 2003. (For the first year of the reform since 2002, people who didn't pass the Examination before came to take the Examination, so that the number of registrations is more than 2003.) And the pass rate has begun to become stabilization since 2009, approximately $10 \%$.

\subsection{Entry Condition: Civil Servant Examination.}

Because of Civil Servant Examination, even if the law graduates passed the National Judicial Examination, he/she cannot smoothly entry into the courts. Civil Servant Examination divides into the central and local Examination forms. In China, Civil Service Examination involving judges mainly is the Local Civil Service Examination, and the degree of difficulty is different according to the local economic, social, political and other developments. Meanwhile, the Examinations of Local People's Court, Intermediate People's Court, Higher People's Court and Supreme People's Court are very different. It is interesting to note that China is in the midst of the upsurge of judicial reform.

\subsection{The Pre-Professional Stage: Court Clerks.}

In general, people who have just entered the work of the court cannot immediately become a judge, he/she should bear the Court Clerks Phase for one year or two, or more. The provisions in Article 40 of the China Organic Act of the People's Court has made clear that the people's courts at all levels set Court Clerk System. This is the legal basis of the Clerk of the court system.

At the beginning of the founding of the PRC, due to special historical background, there was a serious shortage of judicial officers of the courts. The judges of the courts mainly were selected from many outstanding persons who were the demobilized officers, the old revolutionary cadres, and the relevant people's organizations. It was true for the Court Clerk, they were mainly assigned from the demobilized soldiers and the relevant department people. [8] Beginning in the 1980, the trial system had become the focus of judicial reform and the focus of attention of community. Modern trials have more and more high request to the Court Clerk. By the 21st century, Court Clerk System is clearly established.

In the early days, the Court Clerk jobs were simple and cumbersome, and somewhat boring. There was no professional requirement of knowledge structure. But now, it's a completely different situation. The Court Clerk jobs are very heavy, the workload of some clerks may exceed many judges. We discover that in practice a lot of works, such as meeting the Parties and mediating disputes, are handled directly by the Court Clerk. Moreover, it might also be noted that the judgments of the many courts are majority drafted by the Court Clerk, and then be submitted to judges to modify. Even some of the Clerks of the courts directly write judgments, and the duty of judges seems to be the signature and the hearing. This phenomenon may be made possible and more spread out through the Post System of judicial reform. 


\subsection{What is the Post System?}

The so-called the Judge Post System of Judicial Reform aims at making more outstanding talents to become judge of the courts. And once the Judges were decided, it cannot be changed within a certain period, except from filling a vacancy. But this Judge Post System of Judicial Reform is resulted in a series of questions. The most serious problem is that more and more judges leave the courts. In 2014, a total of 105 people left the court system, and it included 86 judges. [9] In the final analysis, this Judge Post System of Judicial Reform grievously injured an interest of some judges. And that makes them have to leave courts. Therefore, some scholars believe that "To benefit a good judge” is the best way to implement Judge Post System of Judicial Reform. [10] Because of comparing with the previous, the possibility of becoming a judge is little, someone may never become a judge all of his life.

\section{Two Conflicts Between Law School Education and Judicial Profession in China}

After analyzed the current situation of China's law education, we found that the explosive number increased continuing nearly 20 years, which leaded to the crisis of law school education, and the most obvious one was that the employment situation was not optimistic. At the same time, college school needs to increase employment rate, so that law school are exploring some new educational pattern, for example learning from the American model, but it produces very little effect, and these explorations are still in progress. After the analysis of the mechanism for appointment of judges, we understand that the possibility of becoming a judge is little, someone may never become a judge all of his life. Paradoxically, the law graduates want to become a judge, meanwhile the possibility of becoming a judge is very slim, so more and more people prefer not to enter the court system.

Therefore, it would appear that the conflicts between law school education and judicial profession would be increasing. The following two sections discuss the two conflicts and consider how to fix them.

\subsection{Conflict I: The Comprehensiveness of Law School Education and The Professionalism of Judicial Profession.}

Nowadays, China law school education aims at an overview of the knowledge of law, rather fully understanding the contents of all disciplines. Actually, that is impossible. Four years of legal education do not enable students to fully understand so many contents of law, and let alone actually using them in real life. In the contrary, the court system in China is divided into the Civil Division, the Criminal Court, the Juvenile Court, and so on. This classification is very professional. We take a step back, and say that the law school education may try to get a preliminary understanding of a full range of law disciplines for students. So, students can create a very solid foundation for further learning. But what we need to understand is that these students who only have essential preliminary understanding of law knowledge will finally enter to courts, the consequence is certainly a lot of trouble. The essential preliminary understanding of law knowledge cannot play a significant role in courts. Therefore, some ways, the comprehensiveness of law school education is unable to fully meet the professionalism of judicial profession, and there is a huge rift between them, which urgently need to repair.

It may be difficult to repair the rift in practice perfectly. Because if law school education tends to be more specialized, students would be unable to learn the other department contents of law. And this also has great harm to their future profession of judge. On the contrary, if we do not specialize law school education, it will be hard to meet the demands of specialization of the judges. Therefore, this Article argues that the court system only can accept the rift or conflict

\subsection{Conflict II: The Intellectualism of Law School Education and the Practicalness of Judicial Profession.}

Higher law education is seen by many people as a kind of pure knowledge education at present. Chinese people always focus on theoretical knowledge, this is the study of his learning habits. The intellectualism of law school education causes that many students cannot understand the actual operation of law. But the theory is usually the ideal state of things, and the actual situation is 
changing all the times, so that the theory and actual situation is not identical. Particularly the law as a practical science is like that. Therefore, there has a conflict between the intellectualism of law school education and the practicalness of judicial profession, and what should we do?

This Article argues that the law school education gradually pay attention to the practice of law, for example, it arranges for students to practice of the courts, the Clinical Legal Education, the Case Teaching Method, and so on. That promotes the improvement of students' practical ability. It is something of an improvement, although it is difficult to meet the requirement of practice of the profession of judge. Notwithstanding there has a conflict between the intellectualism of law school education and the practicalness of judicial profession, they are inherently existing a symbiotic relationship. Because the intellectualism serves the practicalness, and in contrast, the practicalness will bring more material and informative material for the intellectualism.

\section{Conclusion}

In China, the law school education is often supposed that it cannot meet the requirements of the profession of judge, and then what are the reasons? This Article explores the present situation of the law school education in china, and it indicates that the employment situation is not optimistic, because of the increasing numbers of China law students. Although law school are proceeding a number of development, it cannot meet the demands of reality. This Article also discusses how to become a judge, and then this Article points out that along with the Post System of judicial reform, there is a puzzling question: more and more judges leave from courts, at the same time, it is more hard to be a judge (it is hard to become a judge in a hurry). This Article argues that there are two conflicts on them. The first conflict is between the comprehensiveness of law school education and the professionalism of judicial profession; the second conflict is between the intellectualism of law school education and the practicalness of judicial profession. In regard to how mending the rift between them, this Article argues that the comprehensiveness of law school education is a necessary precondition for the professionalism of judicial profession, and the relationship between the intellectualism of law school education and the practicalness of judicial profession is symbiotic.

\section{References}

[1]. Yi Jiming. Three Changes of China’s Law Education. Global Law Review. Vol. 33 (2011) No. 3, p.37.

[2]. The data information on: http://www.stats.gov.cn/tjsj/ndsj/

[3]. Information on: http://www.xfrb.com.cn/area/qilu/jiaoyupeixun/2016-06-13/88939.html

[4]. The data information on: http://www.moe.edu.cn/edoas/website18/41/info4341.htm

[5]. Cai Yanmin, Huang Qiaoyan, Zhao Tong. Exploring the Reform of Legal Education Model--From Sun ZhongShan University Legal Clinic Experience. Academic Research. (2002) No. 10, p.68.

[6]. Li Honghai. Unified Judicial Examination and Fostering and Selecting Legal Qualified Talents. China Legal Science, (2012) No. 4, p.54.

[7]. Information on: http://www.lvban365.net/sikao/5744.html

[8]. Liu Wujun. The Clerk of the Court Management System and its Reform. Journal of Shanghai University of Political Science \& Law(The Rule of Law Forum), Vol.19(2004) No. 1, p.40.

[9]. Information on: http://mt.sohu.com/20160421/n445448830.shtml

[10]. Liu Bin. Viewing the Logic of Judge Post System Reform Through the Phenomenon of Judges Leaving Court. The Science of Law. (2015) No. 10, p.56. 